\title{
Modelos estructurales del empaquetamiento aleatorio de partículas esféricas de Tobermorita: una aproximación computacional sencilla
}

\section{Structural models of randomly packed Tobermorite-like spherical particles: A simple computational approach}

\author{
$\underline{\text { R. González-Teresa }}^{(*)}$, V. Morales-Florez ${ }^{(* *)}$, H. Manzano(*) y J. S. Dolado(*,***)
}

Recepción/Received: 11-I-10

Aceptación/Accepted: 15-II-10

Publicado online/Online publishing: 13-V-10

\section{RESUMEN}

En este trabajo y con el objetivo de conjugar el punto de vista atomístico y coloidal, presentamos un método computacional Monte Carlo que reproduce el empaquetamiento coloidal de nano-partículas esféricas cristalinas de tipo Tobermorita. Variando los parámetros computacionales de empaquetamiento diferentes estructuras tipo Low Density (LD) C-S-H y High Density (HD) C-S-H han sido creadas. Posteriormente, las estructuras resultantes de nuestros experimentos computacionales han sido analizadas en términos de sus densidades, áreas específicas y propiedades mecánicas.

Palabras clave: gel C-S-H, modelo coloidal, simulación computacional.

\section{SUMMARY}

In this work, and in order to bring together the atomistic and colloidal viewpoints, we will present a Monte Carlo computational scheme which reproduces the colloidal packing of nano-spherical crystalline tobermorite-like particles. Different Low Density (LD) C$\mathrm{S}-\mathrm{H}$ and High Density (HD) $\mathrm{C}-\mathrm{S}-\mathrm{H}$ structures will be developed just by varying the computational packing parameters. Finally, the structures resulting from our computational experiments will be analyzed in terms of their densities, surface areas and their mechanical properties.

Keywords: C-S-H gel, colloidal model, modelling.

\section{INTRODUCCIÓN}

Debido a su compleja naturaleza amorfa, la estructura del gel C-S-H no ha sido todavía dilucidada. La mayoría de los conocimientos que se tienen acerca de su nanoestructura han sido obtenidos estableciendo analogías

\section{INTRODUCTION}

Due to its amorphous and complex nature, the structure of cementitious C-S-H is still not fully elucidated. Most insights of its short ordering have been gained from establishing structural analogies with its closest

(*) LABEIN-Tecnalia, Derio (Bizkaia, España).

(**) Centro de Investigaciones de la Cartuja-CSIC. Física de Materiales. Instituto de Ciencia de los Materiales de Sevilla.

(***) Unidad Asociada LABEIN-Tecnalia/CSIC, España.

Persona de contacto/Corresponding author: rgonzalez@labein.es 
estructurales con compuestos cristalinos similares como tobermorita y jennita (1). Cabe destacar que en contraste con las anteriormente mencionadas variedades cristalinas, el orden cristalino del gel C-S-H en el cemento es de corto alcance, con un espectro de difracción de rayos $X$ bastante amorfo (1-2). No obstante, la presencia de ciertos picos característicos de DRX y las conclusiones derivadas de los estudios de ${ }^{29} \mathrm{Si}$ NMR e infrarrojo (IR) (3-6) han permitido describir la estructura del gel C-S-H en base a capas deformadas de tobermorita y jennita (1).

A mayores escalas (desde un nanometro hasta cientos de nanometros), la estructura del gel C-S-H se estudia habitualmente por modelos centrados en las propiedades coloidales del gel (7-9). El esquema más aceptado es el dado por los dos trabajos de Jennings; los llamados Modelo Coloidal I (CM-I) (10) y Modelo Coloidal II (CM-II) (11). El CM-I fue desarrollado para racionalizar el gran número de datos experimentales permitiendo así cuantificar satisfactoriamente parámetros como las densidades, porosidades o superficies específicas (SSA). El punto de partida del CM-I fue la suposición de que existen ciertas partículas esféricas fundamentales (BBB), de 2,4 nm de diámetro, muy secas. y densas, que floculan para formar partículas secundarias de aproximadamente $5 \mathrm{~nm}$ de diámetro llamadas glóbulos. Mientras la densidad de las unidades más pequeñas se fija en valores próximos a $2,8 \mathrm{~g} / \mathrm{cm}^{3}$, la densidad de los glóbulos puede variar desde $2,0 \mathrm{~g} / \mathrm{cm}^{3}$ a $2,44 \mathrm{~g} / \mathrm{cm}^{3}$ dependiendo del contenido de agua intra-globular. El modelo propone también que los glóbulos puedan agregarse para formar un gel C-S-H de baja densidad (LD), con un rango de densidades que oscila entre $1,44 \mathrm{~g} / \mathrm{cm}^{3}$ y $2,013 \mathrm{~g} / \mathrm{cm}^{3}$, o un gel CS-H de alta densidad (HD) cuyo rango de densidades va desde $1,75 \mathrm{~g} / \mathrm{cm}^{3}$ a $2,195 \mathrm{~g} / \mathrm{cm}^{3}$. Parte fundamental del modelo son también las estimaciones hechas para las superficies específicas de las unidades de C-S-H; (BBBs, glóbulos y partículas de LD y HD-C-S-H) y el establecimiento de una relación consistente con los datos obtenidos experimentalmente usando diferentes técnicas. De acuerdo con el CM-I, técnicas como NMR pueden explorar los detalles más pequeños del gel $\mathrm{C}-\mathrm{S}-\mathrm{H}$, siendo capaces de resolver características a escala globular, mientras que técnicas como la Difracción de Neutrones (SANS) o Nitrógeno $\left(\mathrm{N}_{2}\right)$ sólo pueden acceder a la superficie de los glóbulos de las estructuras de baja densidad (LD). En comparación con el CM-I, el CM-II detalla en mayor profundidad la estructura de los glóbulos, centrándose en la interpretación de las isotermas de absorción de agua. Partiendo del conocimiento obtenido recientemente a través de medidas de Difracción de Neutrones (SANS) (12), las cuales han determinado con gran precisión tanto la densidad como la composición y tamaño de los glóbulos saturados $\left(2,6 \mathrm{~g} / \mathrm{cm}^{3}, \mathrm{C}_{1.7}-\mathrm{S}-\mathrm{H}_{1.8}, 4,2 \mathrm{~nm}\right.$ de diámetro respectivamente), el CM-II incorpora estos valores para estimar la densidad y el contenido en agua del C-S-H bajo diferentes condiciones de humedad. crystalline compounds tobermorite and jennite (1). It is worth noting that in contrast to the above crystalline $\mathrm{CSH}$ varieties, the crystalline order of cementitious $\mathrm{C}-\mathrm{S}-\mathrm{H}$ gel is very short-ranged, with a quite amorphous $X$-ray diffraction (XRD) pattern (1-2). Nevertheless, the persistence of certain XRD hallmarks and the conclusions derived from ${ }^{29} \mathrm{Si} N \mathrm{NR}$ and infrared (IR) studies (3-6) have widely accept that the structure of $\mathrm{C}-\mathrm{S}-\mathrm{Hgel}$ is made of distorted layers of tobermorite and jennite (1).

At larger scales (let say from one nanometer to hundreds of nanometers), C-S-H nanostructure is usually studied by models which pay attention to its colloidal and gel-like properties (7-9). Current picture is the one given by two subsequent works of Jennings; the so called Colloidal model I (CM-I) (10) and Colloidal model II (CM-II) (11). The CM-I was essentially developed to rationalise a wide and scattered experimental data and allowed to successfully quantify parameters like densities, porosities or specific surface areas (SSA). The starting point of the CM-I was the assumption that very dried, dense and small (2.4 nm across) spherical basic buildings blocks (BBB) exist and flocculate to form $\sim 5-\mathrm{nm}$ sized secondary particles named globules. While the density of the smallest units is fixed to values close to $2.8 \mathrm{~g} / \mathrm{cm}^{3}$, the density of the globules can range from $2.0 \mathrm{~g} / \mathrm{cm}^{3}$ to $2.440 \mathrm{~g} / \mathrm{cm}^{3}$ depending on the "intra-globular" water content. The model also proposes that the globules can aggregate themselves into either a Low Density (LD) C$\mathrm{S}-\mathrm{H}$ variety with densities ranging from $1.440 \mathrm{~g} / \mathrm{cm}^{3}$ to $2.013 \mathrm{~g} / \mathrm{cm}^{3}$ or a High Density (HD) one with densities that go from $1.75 \mathrm{~g} / \mathrm{cm}^{3}$ to $2.195 \mathrm{~g} / \mathrm{cm}^{3}$. Central to the model are also both the estimations made for the SSA of the $C-S-H$ units; (i.e. BBBs, globules and the $L D$ - and $H D$ $\mathrm{C}-\mathrm{S}-\mathrm{H}$ particles) and the establishment of consistent relations with the data obtained by different techniques. According to the CM-I, techniques like NMR can interrogate the smallest insights of $\mathrm{C}-\mathrm{S}-\mathrm{H}$ gel, being capable of resolving features at the scale of the globules, whereas techniques like Small Angle Neutron Scattering (SANS) or Nitrogen $\left(N_{2}\right)$ only access to the surface exposed by the globules of the $L D$ structures. In comparison to the CM-I, the CM-II is basically a deeper insight on the structure of the globules, and focuses on the interpretation of water sorption isotherms. Starting from the knowledge gained recently through Small Angle Neutron Scattering (SANS) measurements (12) which have determined with great accuracy both the density, composition and size of the saturated globules (2.6 $\mathrm{g} / \mathrm{cm}^{3}, \mathrm{C}_{1.7}-\mathrm{S}-\mathrm{H}_{1.8}$, and $4.2 \mathrm{~nm}$ across respectively) the CM-II incorporates these values to estimate the density and water content of $\mathrm{C}-\mathrm{S}-\mathrm{H}$ under different moisture conditions. 
Sin embargo, y a pesar de los extensos esfuerzos hechos en este campo, muchas de las cuestiones referentes a la nanoestructura del C-S-H siguen abiertas. Por ejemplo, no está todavía claro cómo cristales de tipo tobermorita pueden reordenarse para formar tanto las unidades básicas (BBB) del primer modelo (CM-I) como las estructuras globulares descritas en el segundo modelo (CM-II). Además debe tenerse en cuenta que la densidad de la tobermorita de $14 \AA\left(2,2 \mathrm{~g} / \mathrm{cm}^{3}\right)$ difiere mucho de la atribuida al glóbulo $\left(2,6 \mathrm{~g} / \mathrm{cm}^{3}\right)$, siendo el desacuerdo aún mayor en el caso de las BBB $\left(2,8 \mathrm{~g} / \mathrm{cm}^{3}\right)$ del primer modelo (CM-I). Por qué el gel de alta densidad (HD C-S-H) parece virtualmente invisible a las medidas de SANS y al $\mathrm{N}_{2}(10-11)$ es también un punto pendiente que requiere una apropiada justificación. Asimismo, hay un gran vacío referente al posible efecto del empaquetamiento coloidal en la aparición y desaparición del orden a corto alcance.

En este escenario, donde la conexión entre el orden a corto alcance y la estructura coloidal del gel C-S-H del cemento está todavía sin resolver, cualquier pista en la estructura del gel que pudiera ser aportada por las técnicas de modelización y simulación numérica puede ser muy beneficiosa. Varios trabajos de simulación ya han sido descritos en la literatura, pero o bien han prestado atención a la justificación computacional de los cristales de tobermorita y jennita como modelos estructurales (13-14) o bien han determinado diferentes propiedades dinámicas y estructurales asumiendo estos modelos cristalinos (15-19). Desafortunadamente, todos ellos han centrado su atención en el orden a corto alcance del gel $\mathrm{C}-\mathrm{S}-\mathrm{H}$ sin tener en cuenta la conexión a escala coloidal.

Este trabajo tiene como objetivo, precisamente, tanto estimular la discusión anteriormente mencionada abriendo nuevas cuestiones como unir la visión estructural de corto alcance con una descripción coloidal del gel C-S-H. Con esta finalidad, hemos estudiado el empaquetamiento de esferas de tipo tobermorita mediante simulaciones Monte Carlo. Variando el tamaño de las partículas básicas y ajustando los parámetros de simulación, hemos construido BBBs, glóbulos y estructuras LD y HD C-S-H con las mismas densidades descritas en el modelo I de Jennings (CM-I) (10). Posteriormente, hemos analizado las estructuras resultantes en términos de sus tamaños, densidades, SSAs y propiedades mecánicas.

\section{PROCEDIMIENTO DE SIMULACIÓN: FORMACIÓN DE ESTRUCTURAS LD Y HD C-S-H}

En un primer paso, ad-hoc BBBs de tipo tobermorita han sido creadas. Con el objetivo de seguir, en la medida de lo posible, las densidades descritas en el CM-I para los BBBs, la versión más densa del grupo de tobermorita,
However, and despite the extensive efforts made in this field, several open questions persist regarding the $\mathrm{C}-\mathrm{S}-\mathrm{H}$ nanostructure. For instance, it is still unclear how tobermorite-like crystals can rearrange themselves to form either the dense basic building blocks of the CM-I or the globules described in the CM-II. Lets note that the density of $14 \AA$ tobermorite $\left(2.2 \mathrm{~g} / \mathrm{cm}^{3}\right)$ largely differs from that currently ascribed to the globule $\left(2.6 \mathrm{~g} / \mathrm{cm}^{3}\right)$ or that a still worse comparison can be made with the dense BBBs $\left(2.8 \mathrm{~g} / \mathrm{cm}^{3}\right)$ of the CM-I. Why HD C-S-H gel seems to be virtually invisible to SANS and $N_{2}(10-11)$ measurements is also a pending point which requires a proper justification. Likewise, and to the best of our knowledge, there is a wide gap concerning the potential effect of the colloidal packing on the appearance and disappearance of short-range ordering.

In this scenario, where the debate about the linkage between the short-range ordering and colloidal structure of cementitious $\mathrm{C}-\mathrm{S}-\mathrm{H}$ gel is still unsettled, any hint on the structure of $\mathrm{C}-\mathrm{S}-\mathrm{H}$ gels which can be provided by modelling and numerical simulation techniques would be tremendously beneficial. Some attempts have been already made, but either they have paid attention to the computational justification of the jennite and tobermorite crystals as appropriate structural models (13-14) or they have determined different structural and dynamical properties by assuming these crystalline models (15-19). Unfortunately, all of them have centred their attention to the short-ordering of $\mathrm{C}-\mathrm{S}-\mathrm{H}$, being the linkage with the colloidal scale not covered.

This work aims precisely to stimulate the discussion in the above mentioned open questions and bring together the short-ordering and colloidal descriptions of $\mathrm{C}-\mathrm{S}-\mathrm{H}$ gel. To this end we have studied the packing of tobermorite-like spherical particles through Monte Carlo simulations. By varying the size of the basic particles and adjusting the simulation parameters, we have constructed BBBs, globules and $L D$ and $H D C-S-H$ structures with the same densities as those ascribed in the CM-I (10). Afterwards, we have analyzed the resulting structures in terms of their sizes, densities, SSAs, and mechanical properties.

\section{SIMULATION PROCEDURE: FORMATION OF LD- AND HD C-S-H STRUCTURES}

In a first step, ad-hoc tobermorite-like spheres have been created. In order to follow as much as possible the densities ascribed by CM-I to the BBBs, the densest version of tobermorite group, namely the $9 \AA$ 
llamada tobermorita $9 \AA$ (T9) (20), ha sido elegida como modelo estructural para rellenar esferas de 2,4 nm de diámetro (ver Figura 1(a)). Como se puede apreciar en la Tabla 1, el tamaño $(2,4 \mathrm{~nm})$ y la densidad $\left(2,8 \mathrm{~g} / \mathrm{cm}^{3}\right)$ de nuestras unidades fundamentales coinciden con los valores propuestos por el CM-I. Aunque los tamaños de los BBBs han sido fijados para obtener los mismos valores que en el CM-I (2,4 nm), el valor de la densidad puede considerarse un output de nuestro algoritmo numérico. tobermorite (T9) (20), has been chosen as structural model to fill up the our starting $2.4 \mathrm{~nm}$ sized spheres (see Figure 1 (a)). As can be seen in Table 1, both the size $(2.4 \mathrm{~nm})$ and the density $\left(2.8 \mathrm{~g} / \mathrm{cm}^{3}\right)$ of our basic building blocks coincide with the values proposed by the CM-I. Though the sizes of the BBBs were fixed to the values proposed in the CM-I $(2.4 \mathrm{~nm})$, we regard this value of the density as an output rather than an input of our numerical algorithm.

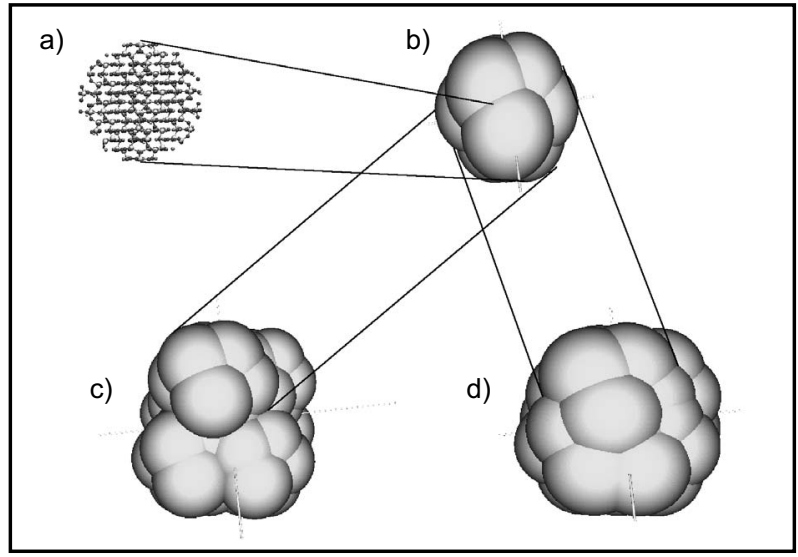

Figura 1. a) Esfera de T9; b) glóbulo; c) estructura LD C-S-H; d) estructura HD C-S-H.

Figure 1. a) Sphere of T9; b) globule; c) LD C-S-H structure; d) $H D C-S-H$ structure.

Tabla 1 / Table 1

Factores de empaquetamiento $(\Phi)$, densidades $(\rho)$, y tamaños (D) de las partículas derivadas de nuestras simulaciones y aquellas presentadas en el CM-I (10).

Packing factors $(\Phi)$, densities $(\rho)$, and sizes $(D)$ of the particles derived from our simulations and those reported in the CM-I (10).

\begin{tabular}{|c|c|c|c|c|c|c|}
\hline & $\begin{array}{c}\Phi \\
\text { Este trabajo / } \\
\text { This work }\end{array}$ & $\begin{array}{c}v\left(\mathbf{g} / \mathrm{cm}^{3}\right) \\
\text { Este trabajo / } \\
\text { This work }\end{array}$ & $\begin{array}{c}\text { Diámetro } \mathrm{D}(\mathrm{nm}) \\
\text { Este trabajo / } \\
\text { Size } D(n m) \\
\text { This work }\end{array}$ & $\begin{array}{c}\Phi \\
\text { CM-I }\end{array}$ & $\underset{\mathrm{CM}-\mathrm{I}}{\rho\left(\mathrm{g} / \mathrm{cm}^{3}\right)}$ & $\begin{array}{c}\text { Diámetro D / } \\
\text { Size } D(\mathrm{~nm}) \\
\mathrm{CM}-\mathrm{I}\end{array}$ \\
\hline BBB & - & 2.8 & 2.4 & - & 2.8 & 2.4 \\
\hline Glóbulo / Globule & 0.83 & 2.33 & 3.6 & 0.82 & 2.3 & 5.6 \\
\hline LD & 0.62 & 1.44 & 7.4 & 0.63 & 1.44 & $\begin{array}{l}18.6 \\
\end{array}$ \\
\hline $\mathrm{HD}$ & 0.75 & 1.75 & 5.9 & 0.76 & 1.75 & $>200$ \\
\hline
\end{tabular}

Seguidamente, y una vez las partículas de T9 han sido construidas, hemos simulado su empaquetamiento a través de un esquema de empaquetamiento jerárquico basado en simulaciones Monte Carlo (21-22).

Primero hemos construido diferentes glóbulos situando una partícula BBB en el espacio y rodeándola aleatoriamente por otras BBBs con un factor de empaquetamiento $\left(\Phi_{\mathrm{G}}\right)$ dado. En las simulaciones, el factor de empaquetamiento puede variarse cambiando las distancias de contacto entre las partículas. En nuestra caso se ha escogido un factor de empaquetamiento $\Phi_{\mathrm{G}}=0,83$ para construir el glóbulo mostrado en la Figura1 (b). Como el factor de empaquetamiento ha sido elegido lo más
Afterwards, and once the spherical particle of T9 has been constructed, we have simulated their packing through a hierarchical packing scheme based on Monte Carlo simulations (21-22).

First we have constructed different globules by placing an elemental particle in the space and randomly surrounding it by other particles with a given packing factor $\left(\Phi_{G}\right)$. In the simulations, a full range of packing efficiencies can be achieved by playing with the contact distances between particles. In our practical realization a packing factor $\Phi_{G}=0.83$ has been taken to construct the globule shown in Figure 1 (b). As the packing factor has been taken to be as close as possible to the values 
cercano posible a los valores descritos en el CM-I (10) y en ref. (23), la densidad resultante de nuestro glóbulo concuerda bien con las descritas para glóbulos secos $\left(2,33 \mathrm{~g} / \mathrm{cm}^{3}\right)$ (ver Tabla 1$)$. Cabe destacar, no obstante, que nuestras simulaciones predicen glóbulos de tamaño más pequeño $(3,6 \mathrm{~nm})$ que el CM-I $(5,6 \mathrm{~nm})$. Este desacuerdo está claramente atribuido al hecho de que en nuestras simulaciones el tamaño de las estructuras está unívocamente determinado por el esquema de empaquetamiento, mientras que en el CM-I el tamaño de las partículas fue ajustado para explicar las SSAs.

En segundo lugar, los glóbulos fueron empleados para desarrollar el segundo nivel de empaquetamiento; es decir, aquél que nos da las partículas de LD y HD C-S-H. El procedimiento de empaquetamiento ha sido realizado de un modo similar, rodeando aleatoriamente un glóbulo por otros glóbulos. Los factores de empaquetamiento fueron ajustados para obtener los valores propuestos en la literatura para el LD C-S-H y el HD C-S-H $\left(\Phi_{\mathrm{LD}}=0,62\right.$ y $\Phi_{H D}=0,75$, respectivamente). Las resultantes estructuras para las partículas de LD C-S-H y HD C-S-H pueden verse en la Figura1 (c) y Figura 1 (d) respectivamente, y sus densidades y tamaños han sido recogidos en la Tabla 1. Como era de esperar, estos tamaños difieren bastante de los tamaños propuestos en el CM-I. De acuerdo con nuestras simulaciones, las partículas de LD C-S-H y HD C-S-H deben tener un diámetro de $\sim 7-8 \mathrm{~nm}$ y $\sim 6 \mathrm{~nm}$, respectivamente. Estos tamaños difieren bastante de los valores propuestos previamente en el CM-I. De hecho, el tamaño atribuido a las partículas de LD C$\mathrm{S}-\mathrm{H}$ en el CM-I es $\sim 18 \mathrm{~nm}$, casi tres veces mayor que nuestro valor. La discrepancia es aún mayor cuando se analizan las partículas de HD C-S-H. Es importante destacar que en el CM-I las partículas de HD C-S-H no tienen tamaño definido (>200 nm) debido a que no tienen contribución en las SSAs.

\section{RESULTADOS}

\subsection{Superficies específicas}

En el CM-I, el tamaño de las partículas no está ligado al esquema de empaquetamiento pero sí a las medidas de SSAs. De hecho, hay una relación directa entre tamaño (D) de las partículas y sus supuestas superficies específicas en términos de su densidad $(\rho)$; es decir, SSA $=6 / \rho D$. Por otra parte, en nuestros experimentos computacionales, el tamaño de las partículas es una consecuencia natural del esquema de empaquetamiento. Como se ha visto anteriormente, nuestros experimentos numéricos proporcionan partículas mucho más pequeñas que aquellas dadas en el CM-I y por tanto, se pueden esperar valores mucho mayores para las superficies específicas. Para analizar este aspecto más detenidamente, hemos estimado found in the CM-I (10)and in ref (23), the resulting density of our constructed globule also fits well with those ascribed to the dried globules $\left(2.33 \mathrm{~g} / \mathrm{cm}^{3}\right.$ ) (see Table 1). It is worth noting, however, that our simulations predict much smaller globules $(3.6 \mathrm{~nm})$ than those of the CM-I $(5.6 \mathrm{~nm})$. This mismatch is clearly attributable to the fact that in our simulations the size of the structures is univocally determined by the packing scheme, whereas in the CM-I the sizes of the particles were adjusted to explain the SSAs.

Second, the globules were employed to develop the second level packing; i.e. the one giving both the $L D$ and $H D-C-S-H$ particles. The packing procedure was done in a similar fashion, randomly surrounding a globule by other globules. The packing factors were adjusted to be the values proposed in the literature for the $L D C S H$ and HD C-SH $\left(\Phi_{L D}=0.62\right.$ and $\Phi_{H D}=0,75$ respectively). The resulting structures for the $L D-C-S-H$ and $H D C-S-H$ particles can be seen in Figure 1 (c) and Figure 1 (d) respectively, and their densities and sizes are collected in Table 1. As expected, our structures are much smaller than those of CM-I. According to our simulations, the LD C-S-H and HD C-S-H particles should be $\sim 7-8 \mathrm{~nm}$ and $\sim 6 \mathrm{~nm}$ sized respectively. These figures largely differ from the values proposed previously. In fact the size ascribed to the $L D C-S-H$ particle in the CM$I$ is $\sim 18 \mathrm{~nm}$, a figure almost three times larger than our value. The discrepancy is even larger when analyzing the HD C-S-H particles. It is worth noting that in the CM-I the $H D C-S-H$ particles have a non-defined size (> $200 \mathrm{~nm}$ ) as they have no contribution to the SSAs.

\section{RESULTS}

\subsection{Surface Areas}

In the CM-I, the size of the particles was not linked to the packing scheme but to the SSAs measurements. In fact, there was a direct relationship between the size (D) of the particles and their supposed SSA in terms of their density $(\rho)$; i.e. $S S A=6 / \rho D$. On the other hand, in our computational experiments, the size of the particles is a natural consequence of their packing scheme. As shown previously, our numerical experiments give much smaller particles than those reported in the CM-I, and therefore, one would expect much higher values for the specific surface areas. To analyze this aspect in further detail, we have computationally estimated the SSAs derived from $\mathrm{N}_{2}$ physisorption measurements, by exploring the 
computacionalmente las SSAs derivadas de medidas de fisisorción de $\mathrm{N}_{2}$, explorando las superficies de las estructuras formadas mediante una partícula de tamaño finito $(0,227 \mathrm{~nm})$; es decir, el tamaño de la molécula de $N_{2}$. Los resultados se pueden encontrar en la Tabla 2. surfaces of the formed structures by a single test particle of finite size $(0.227 \mathrm{~nm})$; i.e. the size of the $\mathrm{N}_{2}$ molecule. The results can be found in the Table 2 .

Tabla 2 / Table 2

Valores de superficie específica para nuestras simulaciones en comparación con los datos empleados en el CM-I. Un factor de 1,82 (26) ha sido aplicado para cambiar los valores de la ref (28) de $\mathrm{m}^{2} / \mathrm{g}$ pasta "D-dried "a m²/g de C-S-H "D-dried".

Specific surface area values for our simulations and the in comparison to the data employed by the CM-I. A factor of 1.82 (26) has been applied to the change the experimental values of ref (28) from $\mathrm{m}^{2} / \mathrm{g} D$-dried paste to $\mathrm{m}^{2} / \mathrm{g}$ of $\mathrm{D}$-dried C-S-H.

\begin{tabular}{|c|c|c|c|}
\hline & $\begin{array}{c}\text { SSA }\left(\mathbf{m}^{2} / \mathbf{g}\right) \\
\text { Este trabajo / This work }\end{array}$ & $\begin{array}{c}\text { SSA }\left(\mathbf{m}^{\mathbf{2}} \mathbf{/ g}\right) \\
\mathbf{C M}-\mathbf{I}\end{array}$ & Exp. $\left(\mathbf{m}^{2} / \mathbf{g}\right)$ \\
\hline Glóbulo / Globule & 190.7 & 460 & 225 SANS (24-26) \\
\hline LD & 103.68 & 250 & - \\
\hline HD & 63.49 & 0 & - \\
\hline C-S-H & $68-100$ & 125 & $38-100 \mathrm{~N}_{2}(28)$ \\
\hline
\end{tabular}

Cuando se comparan los valores para las superficies específicas de sistemas creados en este trabajo con el CM-I, cabe destacar que nuestros valores son menores, a pesar de trabajar con estructuras más pequeñas. Nuestras simulaciones predicen valores de $190 \mathrm{~m}^{2} / \mathrm{g}$ para los glóbulos y valores de $\sim 100 \mathrm{~m}^{2} / \mathrm{g}$ y $\sim 65 \mathrm{~m}^{2} / \mathrm{g}$ para las estructuras de $\mathrm{LD}$ y $\mathrm{HD}$, respectivamente. Es reseñable el hecho de que las superficies específicas de nuestros glóbulos coincidan razonablemente con las obtenidas experimentalmente mediante neutrones $\sim 225 \mathrm{~m}^{2} / \mathrm{gc}$-S-H (24-26). En el caso del CM-I las superficies específicas medidas mediante SANS fueron explicadas asumiendo que los glóbulos pertenecientes a las estructuras HD son invisibles a los neutrones. En nuestro caso esta drástica aproximación no es necesaria. Por otra parte, nuestros resultados muestran directamente la baja contribución de la estructura HD a las SSAs, hecho consistente con el CMI y otros trabajos (27). En este trabajo, las superficies expuestas de las estructuras LD ( 105 m²/g) doblan los valores encontrados para las estructuras HD $\left(\sim 65 \mathrm{~m}^{2} / \mathrm{g}\right)$. Con el objetivo de estimar los valores medidos en los experimentos de fisisorción de $\mathrm{N}_{2}$, dos casos han sido considerados. Primeramente, puede asumirse, que como el CM-I propone, las medidas de $\mathrm{N}_{2}$ no consideran las superficies del HD C-S-H y sólo tienen en cuenta la contribución proveniente de las partículas de LD. En tal caso las resultantes superficies específicas son del orden de 0,65 x 105 $\mathrm{m}^{2} / \mathrm{g}=68,5 \mathrm{~m}^{2} / \mathrm{g}_{\mathrm{C}-\mathrm{S}-\mathrm{H}}$, donde las proporciones de las variedades LD y HD (65\% y $35 \%$, respectivamente) son las dadas por el modelo de Tennis y Jennings (27) para una relación agua/cemento $=0,5$. En segundo lugar, podemos asumir que las variedades HD también contribuyen a las SSAs. En tal caso, las medidas de $\mathrm{N}_{2}$ son de aproximadamente $0,65 \times 105 \mathrm{~m}^{2} / \mathrm{g}+0,35 \times 65 \mathrm{~m}^{2} / \mathrm{g}=91 \mathrm{~m}^{2} / \mathrm{gc}-\mathrm{s}-\mathrm{H}$. Nuestras simulaciones no pueden discernir que caso es el correcto, pero los valores obtenidos son consistentes con los datos experimentales ( $38 \mathrm{~m}^{2} / \mathrm{gc}_{\mathrm{C}-\mathrm{S}-\mathrm{H}}$ para las muestras "oven-dried "y 100 m²/gc-s-H para las" D-dried ") (28).
When comparing the values for the specific surface areas of the systems created in this work with the CM$I$, it is noteworthy that our values are lower, in spite of working with smaller structures. Our simulations predict $190 \mathrm{~m}^{2} / \mathrm{g}$ for the globules and values of $\sim 100 \mathrm{~m}^{2} / \mathrm{g}$ and $\sim 65 \mathrm{~m}^{2} / \mathrm{g}$ for the $L D$ and HD structures respectively. It is remarkable that the SSAs of our globules match reasonably well with the SSAs experimentally observed by neutrons (225 m²/gcSH) (24-26). In the case of CM-I the SSAs measured by SANS were explained by assuming that the globules belonging to the $H D$ structures are invisible to the neutrons. In our case, this drastic approximation is not needed. On the other hand, our results directly show the lower contribution of the $H D$ arrangements to the SSAs, something consistent with the CM-I and other works (27). In our case, the surfaces exposed by the $L D$ arrangements ( $105 \mathrm{~m}^{2} / \mathrm{g}$ ) almost double the values found for the HD structures ( $65 \mathrm{~m}^{2} / \mathrm{g}$ ). In order to estimate the values measured in the $\mathrm{N}_{2}$ sorption experiments, two cases can be proposed. Firstly, we can assume, as CM-I proposes, that $\mathrm{N}_{2}$ measurements miss the HD C-S-H surfaces and account only for the contribution coming from the $L D$ particles. In such a case the resulting SSAs are about $0.65 \times 105 \mathrm{~m}^{2} / \mathrm{g}=68.5 \mathrm{~m}^{2} / \mathrm{g}_{\mathrm{CSH}}$, where the proportions of $L D$ and $H D$ varieties (65\% and $35 \%$ respectively) are given by the model of Tennis and Jennings (27) for a $w / c=0.5$. Secondly we can assume that $H D$ varieties also contribute to the SSAs. In such a case the $\mathrm{N}_{2}$ measurements would explore $0.65 \times 105+0.35 \times 65=$ $91 \mathrm{~m}^{2} / g_{\mathrm{CSH}}$. Our simulations cannot rule out any of these two possibilities. Nevertheless, the values are consistent with the experimental values $\left(38 \mathrm{~m}^{2} / \mathrm{gCSH}_{\mathrm{CO}}\right.$ for oven-dried samples and $100 \mathrm{~m}^{2} / g_{C S H}$ for $D$-dried samples) (28) 


\section{Propiedades mecánicas}

Diversos trabajos computacionales (15-16) han mostrado que las propiedades elásticas dependen linealmente de las densidades. Desde un punto de vista práctico, Manzano (29) ha encontrado que en el caso particular de los cristales tipo tobermorita y jennita, tanto el módulo de Young (E) como el módulo elástico transversal (G) pueden ser expresados en términos de la densidad $(\rho)$ de acuerdo con la regresión lineal tal como se observa en las ecuaciones [1] y [2]:

\section{Mechanical properties}

Different computational works (15-16) have shown that the elastic properties are linearly related to the densities. From a practical viewpoint, Manzano (29) has found that in the particular case of tobermorite- and jennite-like crystals, both the Young modulus ( $E$ ) and Shear modulus (G) can be expressed in terms of the density ( $\rho$ ) according to the linear fittings shown in equations [1] and [2]:

$$
\begin{aligned}
& E(\mathrm{GPa})=78.88 \rho\left(\mathrm{g} / \mathrm{cm}^{3}\right)-123.3 \\
& G(\mathrm{GPa})=31.50 \rho\left(\mathrm{g} / \mathrm{cm}^{3}\right)-50.30
\end{aligned}
$$

Seguidamente, el módulo de compresibilidad (K) y el coeficiente de Poisson $(v)$ pueden ser determinados a partir de $\mathrm{E}$ y $\mathrm{G}$ asumiendo un medio isotrópico:
Later, the Bulk modulus ( $K$ ) and Poisson coefficient ( $n$ ) can bedetermined from $E$ and $G$ assuming an isotropic media:

$$
\begin{array}{r}
K=\frac{G E}{3(3 G-E)} \\
v=\frac{E}{2 G}-1
\end{array}
$$

Finalmente, y para obtener una mejor comparación con los resultados obtenidos en los experimentos de nanoidentación, hemos calculado el módulo de identación (M), el cual se define de acuerdo a
Finally, and for the sake of a best comparison with the experimental nanoindentation results, we have calculated the Indentation modulus $(M)$, which is defined according to

$$
M=\frac{E}{\left(1-v^{2}\right)}
$$

En este trabajo hemos empleado las relaciones vistas en las ecuaciones [1-5] para estimar las propiedades de las unidades fundamentales (BBBs) y de los glóbulos. El módulo de identación (ver Tabla 3), parece concordar razonablemente bien con los experimentos. Estudios de nanoidentación (30) han determinado que la rigidez (M) de los glóbulos de C-S-H es aproximadamente $60 \mathrm{GPa}$. Nuestra predicción ( $\mathrm{M}=66 \mathrm{GPa}$ ) se acerca bastante a la estimación experimental. Después, las propiedades elásticas de las partículas de LD y HD C-S-H han sido calculadas usando el modelo micromecánico llamado "Self-Consistent" (31) empleando como inputs tanto las propiedades elásticas de los glóbulos como los factores de empaquetamiento de las partículas de LD y $\mathrm{HD}\left(\Phi_{\mathrm{LD}}=0,62\right.$ y $\Phi_{\mathrm{HD}}=0,75$, respectivamente). Como en casos anteriores, los resultados se recogen en la Tabla 3. Cabe destacar, que nuestras predicciones para el módulo de identación de las estructuras LD y HD $(19,1 \mathrm{GPa}$ y 35,1 ) están dentro del rango medido (23) para estas partículas.
In this work we have employed the relationships shown in Eq. [1-5] to estimate the elastic properties of the BBB and the globules. The indentation modulus (see Table 3), seems to fit reasonably well with the experiments. Accurate nanoindenting studies (30) have determined by back analysis that the solid stiffness (M) of the C-S-H globules are something about $60 \mathrm{GPa}$. Our prediction ( $M=66 \mathrm{GPa})$ is very close to the experimental estimation. Afterwards, the elastic properties of the $L D$ and $H D C-S-H$ particles have been calculated by using the Self-Consistent micromechanical model (31) and employing as inputs the elastic properties of the globules and the packing factors of the $L D$ and $H D$ particles $\left(\Phi_{L D}=0.62\right.$ and $\Phi_{H D}=0.75$ respectively). As in previous cases, the results are collected in the Table 3. Notably, our predictions for the Indentation modulus of the $L D$ and HD- structures (19.1 GPa and 35.1) lay within the range measured (23) for these particles. 
Tabla 3 / Table 3

Valores para el módulo de compresibilidad, módulo elástico transversal, modulo de Young, coeficiente de Poisson y módulo de indentación en comparación con los datos experimentales.

Values for the Bulk modulus, Shear modulus, Young modulus, Poisson's ratio and Indentation module in comparison to the experimental data.

\begin{tabular}{|c|c|c|c|c|c|c|}
\hline & K (GPa) & G (GPa) & E (GPa) & $v(\mathbf{G P a})$ & M (GPa) & $\begin{array}{c}\text { M (GPa) Exp. } \\
(\mathbf{2 3 , 3 0})\end{array}$ \\
\hline BBB & 75.2 & 37.9 & 97.3 & 0.28 & 105 & \\
\hline Glóbilo / Globule & 51.5 & 23.1 & 60.3 & 0.3 & 66 & 60 \\
\hline LD & 32.5 & 5.7 & 16.3 & 0.4 & 19.4 & $13-26$ \\
\hline HD & 39.1 & 11.8 & 32.2 & 0.3 & 35.1 & $26-39$ \\
\hline
\end{tabular}

\section{CONCLUSIONES}

Este trabajo presenta un modelo computacional Monte Carlo que reproduce el empaquetamiento coloidal de partículas tipo tobermorita. Comenzando con esferas de T9, las variables de nuestro protocolo computacional han sido modificadas para construir los glóbulos de C-S-H y las partículas de LD y HD C-S-H con el objetivo de obtener las mismas densidades dadas en el CM-I. Seguidamente hemos analizado las estructuras formadas en términos de sus tamaños, SSAs, y propiedades mecánicas. Siendo el tamaño de nuestras partículas una consecuencia de nuestro esquema de empaquetamiento, los valores encontrados han resultado ser notablemente menores que los propuestos en el CM-I. Este hecho no representa un problema a la hora de describir las SSAs, con tal que éstas se describan a través de experimentos numéricos de fisisorción de $\mathrm{N}_{2}$. Finalmente, hemos evaluado las propiedades elásticas de los glóbulos y de las partículas de LD y HD C-S-H, obteniendo valores dentro del rango experimental.

\section{AGRADECIMIENTOS}

Este trabajo ha sido respaldado económicamente por el proyecto CODICE, bajo el programa NMP del FP7, proyecto 214030 . R. González-Teresa y H. Manzano agradecen la beca recibida de la asociación EITE.

\section{CONCLUSIONS}

This work presents a computational Monte Carlo scheme to reproduce the colloidal packing of the tobermorite like particles. By starting from T9 spheres, the variables of our computational protocol have been tuned to construct $C-S-H$ globules, LD- and HD- C-S-H particles with the same densities as those reported in the CM-I. Afterwards we have analysed the so formed structures in terms of their sizes, SSAs and mechanical properties. Being the size of our particles a direct outcome of our packing scheme, the values we have found are notably smaller than sizes proposed in the CM-I. Interestingly, we have seen that this does not entail an unsurmountable problem when describing the SSAs, provided that realistic numerical $N_{2}$-physisorption experiments are carried out. Finally, we have evaluated the elastic properties of the globules and $L D$ - and $H D-C-S-H$ particles, laying our figures within the experimental range.

\section{ACKNOWLEDGEMENTS}

This work has been economically supported by the CODICE project, under the NMP program of the FP7, Grant agreement no: 214030. R. González-Teresa and H. Manzano acknowledge the grant received from the EITE association.

\section{BIBLIOGRAFÍA / BIBLIOGRAPHY}

(1) Taylor, H. F. W.: "Proposed structure for calcium silicate hydrate gel", Journal of the American Ceramic Society, vol. 69 (6) (1986), pp. 464-467. doi:10.1111/j.1151-2916.1986.tb07446.x

(2) Richardson, I. G.: "Tobermorite/jennite- and tobermorite/calcium hydroxide-based models for the structure of C-S-H: applicability to hardened pastes of tricalcium silicate, beta-dicalcium silicate, Portland cement, and blends of Portland cement with blast-fumace slag, metakaolin, or silica fume", Cement and Concrete Research, vol. 34 (9) (2004), pp. 1733-1777. doi:10.1016/j.cemconres.2004.05.034 (3) Cong, X. and Kirkpatrick, R. J.: "29Si MAS NMR study of the structure of calcium silicate hydrate", Adv. Cem. Based Mater, vol. 3 (1996), pp. 144-146. doi:10.1016/S1065-7355(96)90046-2

(4) Brough, A. R.; Dobson, C. M.; Richardson, I. G., and Groves, G. W.: "In situ solid state NMR studies of $\mathrm{Ca}_{3} \mathrm{SiO}_{5}$ : Hydration at room temperature and at elevated temperatures using 29Si enrichment", Journal of Materials Science, vol. 29 (1994), pp. 3926-3940. doi:10.1007/BF00355951 
(5) Cong, X. and Kirkpatrick, R. J.: "170 MAS NMR Investigation of the structure of the calcium silicate hydrate gel," J. Am. Ceram. Soc., vol. 79 [6] (1996), pp. 1585-92. doi:10.1111/j.1151-2916.1996.tb08768.x

(6) Yu, P.; Kirkpatrick, R. J.; Poe, B.; McMillan, P. F., and Cong, X.: "Structure of calcium silicate hydrate (C-S-H): Near-, mid-, and farinfrared spectroscopy," J. Am. Ceram. Soc., vol. 82 [3] (1999), pp. 742-48.

(7) Powers, T. C.: "Physical properties of cement paste", Fourth International Symposium on Chemistry of Cement, pp. 577-609. Washington, DC, National Bureau of Standards (1960).

(8) Feldman, R. F. and Sereda, P. J.: "A new model of hydrated cement and its practical applications", Eng. J. Can., vol. 53 (1970), pp. 53-59.

(9) Wittmann, F. H.: "Trends in research on creep and shrinkage of concrete in cement production and use". J. Skalny, New Hampshire, pp. 143-161, Engeneering Foundation-New York (1979).

(10) Jennings, H. M.: "A model for the microstructure of calcium silicate hydrate in cement paste", Cem. Concr. Res. vol. 30 (2000), pp. 101-116. doi:10.1016/S0008-8846(99)00209-4

(11) Jennings, H. M.: "Refinements to colloid model of C-S-H in cement", Cem. Concr. Res., vol. 38 (2008), pp. $275-289$. doi:10.1016/j.cemconres.2007.10.006

(12) Allen, A. J., et. al.: "Composition and density of nanoscale calcium silicate hydrate in cement", Nature Materials, vol. 6 (2007), pp. 311-316. doi:10.1038/nmat1871 PMid:17384634

(13) Dolado, J. S., et. al.: Journal of the American Ceramic Society, vol. 90, no 12 (2007), pp. 3938-3942.

(14) Pellenq, R. J.-M. et al.: "A realistic molecular model of cement hydrates"; PNAS vol. 106, no 38 (2009), pp. 16102-16107. doi:10.1073/pnas.0902180106 PMid:19805265 PMCid:2739865

(15) Pelleq, M., et. al.: "Engineering the bonding scheme in C-S-H: the iono-covalent framework", Cement and Concrete Research, vol. 38 (2008), pp. 159-174. doi:10.1016/j.cemconres.2007.09.026

(16) Manzano, H.; Dolado, J. S.; Ayuela, A.: "Elastic properties of the main species present in Portland cement pastes", Acta Materialia, vol. 57, no 5 (2009), pp. 1666-1674. doi:10.1016/j.actamat.2008.12.007

(17) Shahsavari, R., et al.: "First-principles study of elastic constants and interlayer interactions of complex hydrated oxides: case study of Tobermorite and Jennite", Journal of the American Ceramic Society, vol. 92, no10 (2009), pp. 2323-2330. doi:10.1111/j.15512916.2009.03199.x

(18) Gmira, A., et al.: "Microscopic physical basis of the poromechanical behavior of cement-based materials", Materials and Structures, vol. 37 (2004), pp. 3-14. doi:10.1007/BF02481622

(19) Kalinichev, A. G.; Wang, J. and Kirkpatrick, R. J.: "Molecular dynamics modeling of the structure, dynamics and energetics of mineral-water interfaces: Application to cement materials", Cement and Concrete Research, vol. 37 (2007), pp. $337-347$. doi:10.1016/j.cemconres.2006.07.004

(20) Richardson, I.G.: "The calcium silicate hydrates", Cem. Concr. Res., vol. 38 (2008), pp. 137-158. doi:10.1016/j.cemconres.2007.11.005 (21) Morales-Flórez, V., et al. The Cluster Model: "A simulation of the Aerogel Structure as a Hierarchically-Ordered Arrangement of Randomly Packed Spheres". Journal of Sol-Gel Science and Technology, vol. 35 (2005), pp. 203-210. doi:10.1007/s10971-005-2363-4

(22) Morales-Flórez, V. and Brunet, F.: "Structural models of random packing of spheres extended to bricks: Simulation of the nanoporous Calcium-Silicate-Hydrates", Molecular Simulation, vol. 35, no 12-13 (2009), pp. 1001-1006. doi:10.1080/08927020903033117

(23) Constantinedes, G.; Ulm, Franz-Josef: "The nanogranular nature of C-S-H", Journal of the Mechanics and Physics of Solids, vol. 55 (2007), pp. 64-90.

(24) Allen, A. and Thomas, J. J.: "Analysis of cement paste and C-S-H gel by small-angle neutron scattering", Cement and Concrete Research, vol. 37 (2007), pp. 319-324 doi:10.1016/j.cemconres.2006.09.002

(25) Thomas, J. J.; Chen, J. J.; Allen, A. J. and Jennings, H. M..: "Effects of decalcification on the microstructure and surface area of cement and tricalcium silicate pastes"; Cem. Concr. Res., vol. 34 (2004), pp. 2297-2307. doi:10.1016/j.cemconres.2004.04.007

(26) Thomas, Jeffrey J.; Jennings, Hamlin M., and Allen, Andrew J.: "The Surface Area of Hardened Cement Paste as Measured by Various Techniques", Concrete Science and Engineering, vol. 1 (1999), pp. 45-64.

(27) Tennis, P. D. and Jennings, H. M.: "A model of two types of calcium silicate hydrate in the microstructure of Portland cement pastes", Cem. Concr. Res., vol. 30 (2000), pp. 855-863. doi:10.1016/S0008-8846(00)00257-X

(28) Garci Juenger, M. C. and Jennings, H. M: "The use of nitrogen adsorption to asses the microstructure of cement paste", Cem. Concr. Res., vol. 31 (2001), pp. 883-892. doi:10.1016/S0008-8846(01)00493-8

(29) Manzano, H.: "Atomistic Simulation studies of The Cement Paste Components", Thesis; University of the Basque Country UPV/EHU (2009). (30) Constantinides, G. and Ulm, F.-J.: "The nanogranular nature of C-S-H", J. Mech. Phys. Sol., vol. 55 (2007), pp. 64-90. doi:10.1016/j.jmps.2006.06.003

(31) Kröner, E.: Statistical continuum mechanics, Springer-Verla (1972). 